\title{
Role of osteocalcin, tumor necrosis factor-alpha and adiponectin in polycystic ovary syndrome patients with insulin resistance
}

\section{Polikistik over sendromlu hastalarda insülin direncinde osteokalsin, tümör nekroz faktörü-alfa ve adiponektinin rolü}

\author{
Gönül Erkan ${ }^{1}$, Ahter Tanay Tayyar², Gökhan Açmaz ${ }^{3}$ İptisam İpek Müderris ${ }^{4}$, Gülden Başkol ${ }^{5}$, Fahri Bayram ${ }^{6}$ \\ ${ }^{1}$ Private Hüma Hospital, Clinic of Obstetrics and Gynecology, Kayseri, Turkey \\ ${ }^{2} Z$ Eeynep Kamil Maternity and Children's Diseases Training and Research Hospital, Clinic of Obstetrics and Gynecology, İstanbul, Turkey \\ ${ }^{3}$ Kayseri Training and Research Hospital, Clinic of Obstetrics and Gynecology, Kayseri, Turkey \\ ${ }^{4}$ Erciyes University Faculty of Medicine, Department of Obstetrics and Gynecology, Kayseri, Turkey \\ ${ }^{5}$ Erciyes University Faculty of Medicine, Department of Biochemistry, Kayseri, Turkey \\ ${ }^{6}$ Erciyes University Faculty of Medicine, Department of Clinical Endocrinology and Metabolism, Kayseri, Turkey
}

\begin{abstract}
Objective: Insulin resistance (IR) seems to be the main pathogenic factor in polycystic ovary syndrome (PCOS). Adiponectin and tumor necrosis factoralpha (TNF- $\alpha$ ) are important in IR. The aim of this study was to evaluate the correlations of osteocalcin, adiponectin, and TNF- $\alpha$ with IR in PCOS.

Materials and Methods: A total of 60 women were divided into two groups. The first group constituted 44 patients with PCOS and the control group comprised 16 healthy women. Osteocalcin, adiponectin, TNF- $\alpha$ levels, body mass index (BMI), and IR in the fasting state were assessed and correlations of these parameters were evaluated.

Results: Homeostasis model assessment (HOMA)-IR, adiponectin, osteocalcin, and androstenedione levels were significantly increased in the PCOS group. A moderate positive correlation between BMI and HOMA-IR, a moderate negative correlation between TNF- $\alpha$ and osteocalcin, and a mild negative correlation between adiponectin and BMI were detected in PCOS.

Conclusion: Osteocalcin may have impact on adiponectin, TNF- $\alpha$, and IR levels in PCOS. Different osteocalcin levels in patients with PCOS may be responsible for explaining PCOS heterogeneity.

Keywords: Polycystic ovary syndrome, insulin resistance, osteocalcin, adiponectin, tumor necrosis factor-alpha

Öz

Amaç: Polikistik over sendromunun (PKOS) temelinde yatan en önemli mekanizma insülin direncidir (IR). Bu çalışmada PKOS'li hastalarda kan osteokalsin düzeyinin; IR, adiponektin, tümör nekroz faktörü-alfa (TNF- $\alpha$ ) ve bazı hormonal parametrelerle olan ilişkisini değerlendirmeyi amaçladık.

Gereç ve Yöntemler: PKOS tanısına uyan 44 hasta ve hiçbir rahatsızlığı olamayan 16 sağlıklı kontrol grubundan olusan toplam 60 hasta ile yapıldı. Bu hastaların kan osteokalsin, adiponektin, TNF- $\alpha$, vücut kitle indeksi (VKI) ve IR düzeyleri ölçülerek bu parametreler arasındaki ilişki incelendi.

Bulgular: PKOS grubunda homeostaz model değerlendirmesi (HOMA)-IR, adiponektin, osteokalsin ve androstenedion düzeyleri anlamlı olarak yüksek bulundu.VKİ ve HOMA-IR arasında pozitif ilişki bulunurken TNF- $\alpha$ ve osteokalsin, adiponektin ve VKİ arasında negatif ilişki saptandı.

Sonuç: PKOS'li hastalarda kan osteokalsin düzeyinin adiponektin, TNF- $\alpha$, ve IR üzerine etkisi bulunmaktadır. Saptanan farklı osteokalsin düzeyleri PKOS'li hastalarda heterojeniteyi açıklamakta faydalı olabilir.

Anahtar Kelimeler: Polikistik over sendromu, insülin direnci, osteokalsin, adiponektin, tümör nekroz faktörü-alfa
\end{abstract}

Address for Correspondence/Yazışma Adresi: Ahter Tanay Tayyar, MD

Zeynep Kamil Maternity and Children's Diseases Training and Research Hospital, Clinic of Obstetrics and Gynecology, İstanbul, Turkey

Phone: +90 5326176699 E-mail: drahtertayyar@yahoo.com

Received/Geliș Tarihi: 20.12.2016 Accepted/Kabul Tarihi: 16.03.2017

${ }^{\oplus}$ Copyright 2017 by Turkish Society of Obstetrics and Gynecology

Turkish Journal of Obstetrics and Gynecology published by Galenos Publishing House 
PRECIS: Bone is recognized as an endocrine organ. Osteocalcin seems to play a key role in the heterogeneity of polycystic ovary syndrome.

\section{Introduction}

Polycystic ovary syndrome (PCOS) is a common and heterogeneous disease characterized by anovulation, hyperandrogenism, and/or polycystic ovaries ${ }^{(1,2)}$. Therefore, an important consideration is whether such adipocytokines as adiponectin, a potential mediator of insulin resistance (IR), are also implicated in the pathogenesis of $\mathrm{PCOS}^{(3)}$. Levels of adiponectin, an abundant adipocyte-derived cytokine, are strongly correlated with measures of $\mathrm{IR}^{(4,5)}$. Gonzalez et al. ${ }^{(6)}$ illustrated that hyperglycemia caused an increase in reactive oxygen species (ROS) generation from peripheral blood mononuclear cells (MNC). ROS-induced oxidative stress is a known activator of nuclear factor B, a proinflammatory transcription factor that promotes tumor necrosis factor (TNF) gene transcription ${ }^{(7)}$. TNF was established as a mediator of IR by Hotamisligil et al. ${ }^{(8)}$. Thus, increased TNF release from MNC in response to hyperglycemia may be an underlying mechanism for IR in PCOS.

Previous animal studies showed that osteocalcin stimulated the expression of insulin in islets and of adiponectin in adipocytes with increased insulin secretion and sensitivity ${ }^{(9)}$. Reduced osteocalcin levels have been claimed to be associated with diabetes mellitus (DM) development ${ }^{(10)}$. We aimed to evaluate the correlations of blood osteocalcin, adiponectin, and TNF- $\alpha$ levels with IR in PCOS. Additionally, we evaluated the relationship of these with some hormonal parameters.

\section{Materials and Methods}

A total of 60 women including 44 patients with PCOS and 16 healthy women (control group) were studied at Erciyes University Gynecology Clinic. The diagnosis of PCOS was based on the established guidelines by the PCOS Consensus Workshop Group ${ }^{(1)}$. Ultrasonographic diagnosis of polycystic ovaries was based on the presence of 12 or more follicles in each ovary measuring 2-9 $\mathrm{mm}$ in diameter, and/or increased ovarian volume $>10 \mathrm{~mL}$ on pelvic or vaginal ultrasound examination. Oligomenorrhea was defined as the absence of menstruation for 35 days or more and amenorrhea was defined as the absence of menstruation for 3 months or more ${ }^{(1)}$.

All women were examined both clinically and gynecologically including ultrasonography. Body weight, height, and body mass index (BMI) were recorded. The BMI was calculated as weight/ (height $)^{2}$ in kilograms per square meter. The study and control groups were weight matched. Patients with congenital adrenal hyperplasia, androgen-producing tumors, adrenal dysfunction, Cushing's syndrome, hyperprolactinemia, DM, liver, kidney, heart, and thyroid diseases were excluded from the study. None of the women in study or control group had taken medications known to effect plasma sex steroids for $\geq 6$ months before the study and none of the volunteers was a cigarette smoker. All the women agreed to participate in the present study. The study was approved by the Ethics Committee of Erciyes University Hospital (approval number: 2011-369) and written informed consent was obtained from each woman. Moreover, we obtained an Australian-New Zealand clinical trials registry number: 12613001132730.

Fasting state venous blood was collected from the subjects during the midfollicular phase of the menstrual cycle between 08:00 am and 09:00 am. Glucose levels were measured three days after the normal diet and normal daily activity using the oxidase method with Konelab 60-i auto-analyzers (Thermo Clinical Labsystem, Finland). IR in the fasting state was assessed by using homeostasis model assessment (HOMA) and was calculated with the following formula: fasting plasma glucose $(\mathrm{mmol} / \mathrm{L}) \times$ fasting serum insulin $(\mu \mathrm{U} / \mathrm{mL})$ divided by 22.5 , as described by Matthews et al. ${ }^{(11)}$. Hormonal analyses included: thyroid stimulating hormone, dehydroepiandrosterone sulfate (DHEAS), prolactin (PRL), luteinizing hormone (LH), follicle-stimulating hormone (FSH), estradiol (E2), 17-hydroxyprogesterone (17-OHP), androstenedione (A), free testosterone (fT), total testosterone (tT), insulin, and sex hormone binding globulin (SHBG) levels. tT and fT (Biosource, Nivelles, Belgium), 17-OHP (DSL-3500, Texas, USA), DHEAS (Immunotech, Marseille, France), A (DSL3800, Texas, USA) were measured using an immunoradiometric assay and its commercial kit, serum SHBG (Zentech, Angleur, Belgium), insulin (Biosource, Nivelles, Belgium), LH, FSH, P, PRL (ACS:180, Bayer, Germany) were measured using chemiluminescence and a commercial kit. After centrifugation, blood serum was stored at $-70{ }^{\circ} \mathrm{C}$ until assayed. Adiponectin (Adiponectin kit, Assaypro, UK), TNF- $\alpha$ (TNF- $\alpha$ Invitrogen 96 Tests, UK) and osteocalcin (Gla-type osteocalcin in vitro enzyme immunoassay kit, Takara Bio Inc., UK) were measured using an enzyme-linked immunosorbent assay.

The intra and inter-assay precision coefficients of variation were $2.8 \%$ and $4.6 \%$ for FSH, $5 \%$ and $6.2 \%$ for $\mathrm{LH}, 9.9 \%$ and $11.8 \%$ for E2, $4.4 \%$ and $4.8 \%$ for testosterone, $4.3 \%$ and $7.8 \%$ for fT, $11 \%$ and $2.8 \%$ and $7 \%$ for A, $6.3 \%$ and $9.9 \%$ for DHEAS, $9.5 \%$ and $10.8 \%$ for $17-\mathrm{OHP}, 5.2 \%$ and $5.8 \%$ for SHBG, and $1.6 \%$ and $6.1 \%$ for insulin, respectively. All results are expressed as means \pm standard deviation.

\section{Statistical Analysis}

The Shapiro-Wilk test was used to check the normality assumption of the data. Independent samples t-test and MannWhitney $\mathrm{U}$ tests were used to compare the differences of variables between the groups. Pearson and Spearman analysis were used to examine correlations, and a scatterplot matrix was also produced to display pairwise relationships between 
variables. To identify independent risk factors of PCOS, univariate and multivariate logistic regression analysis was used and odds ratios were calculated with their 95\% confidence intervals. Statistically significant variables in univariate analysis were included in the multivariate logistic model and backward stepwise selection was performed at a stringency level of $\mathrm{p}<0.10$ to determine the independent risk factors of PCOS. Two-sided $\mathrm{p}$ values $<0.05$ were considered statistically significant.

\section{Results}

The study and control groups were weight matched. Hormone levels and baseline characteristics of the groups are illustrated in Table 1.

The level of A was significantly high in the PCOS group. There was no statistically significant difference between the groups for age, BMI, DHEAS, FSH, SHBG, LH, fT, tT, and E2.

High levels of HOMA-IR, adiponectin, and osteocalcin were detected in the PCOS group. There was no significant difference between the two groups for TNF- $\alpha$ (Table 1). The cut-off value of HOMA-IR was accepted as $2.5^{(12,13)}$.

We detected a strong positive correlation between adiponectin and osteocalcin in the control group. There was positive correlation between osteocalcin and BMI in addition to a negative correlation between osteocalcin and TNF- $\alpha$ in the PCOS group. We found a moderate positive correlation between BMI and HOMA-IR, a moderate negative correlation between
TNF- $\alpha$ and osteocalcin, and a mild negative correlation between adiponectin and BMI (Table 2, Figure 1).

\section{Discussion}

Many of the symptoms appear to be quite heterogeneous, with marked differences in their prevalence and intensity among different groups of women with PCOS. IR was significantly high in the PCOS group. Some studies showed IR only in obese women with PCOS and others demonstrated IR in lean patients with PCOS. Of importance, the studies that failed to demonstrate IR in lean women with PCOS did, however, demonstrate elevated basal insulin levels compared with weight-matched controls without PCOS ${ }^{(14)}$.

The groups in our study were weight matched; therefore, the effect of adipose tissue on TNF- $\alpha$ and adiponectin was eliminated. We found higher levels of adiponectin in PCOS; however, some authors suggested that women with PCOS had lower adiponectin levels ${ }^{(15)}$. Conversely, an increment in plasma adiponectin was obtained by Frystyk et al. ${ }^{(16)}$ in type 1 DM. One way to interpret the present findings is to conclude that high adiponectin levels may be an early predictor of DM development. Unfortunately, $52.7 \%$ of patients in the PCOS group had IR. However, the finding can also be interpreted in the opposite way, as elevated adiponectin levels could represent a beneficial compensatory mechanism. Several markers of inflammation are increased in PCOS, which suggests that it is

Table 1. Hormonal levels and baseline characteristics of groups

\begin{tabular}{|c|c|c|c|c|c|}
\hline \multirow[t]{2}{*}{ Variables } & \multicolumn{3}{|c|}{ Between-group comparisons } & \multicolumn{2}{|c|}{ Logistic regression analyses } \\
\hline & PCOS group $(n=44)$ & Control group $(n=16)$ & $\mathrm{p}$ & $\begin{array}{l}\text { Univariate } \\
\text { OR }(95 \% \mathrm{CI})\end{array}$ & $\begin{array}{l}\text { Multivariate } \\
\text { OR }(95 \% \text { CI })\end{array}$ \\
\hline Age (years) & $21.50(20.00-24.00)$ & $22.50(19.50-24.75)$ & 0.608 & $0.96(0.81-1.14)$ & - \\
\hline BMI $\left(\mathrm{kg} / \mathrm{m}^{2}\right)$ & $22.50(20.25-26.00)$ & $21.00(20.00-23.00)$ & 0.072 & $1.27(0.98-1.65)$ & - \\
\hline $\mathrm{tT}(\mathrm{pg} / \mathrm{mL})$ & $80.50(49.75-113.25)$ & $72.00(61.25-93.00)$ & 0.77 & $1.01(0.99-1.02)$ & - \\
\hline $\mathrm{fT}(\mathrm{pg} / \mathrm{mL})$ & $2.64 \pm 0.83$ & $2.22 \pm 1.24$ & 0.217 & $1.64(1.60-3.14)$ & - \\
\hline $\mathrm{A}(\mathrm{ng} / \mathrm{mL})$ & $3.05(2.27-4.12)$ & $2.24(2.00-2.98)$ & 0.026 & $1.91(1.03-3.54)$ & - \\
\hline DHEAS (ng/mL) & $2182.34 \pm 125.44$ & $2334.37 \pm 768.27$ & 0.652 & $1.00(0.99-1.01)$ & - \\
\hline SHBG (nmoL/mL) & $47.00(26.50-95.50)$ & $49.50(41.25-85.75)$ & 0.477 & $1.00(0.99-1.01)$ & - \\
\hline FSH (pg/mL) & $5.00(4.00-4.00)$ & $5.30(4.45-7.75)$ & 0.317 & $0.76(0.54-1.08)$ & - \\
\hline $\mathrm{LH}(\mathrm{pg} / \mathrm{mL})$ & $5.30(4.42-9.00)$ & $8.00(5.30-11.75)$ & 0.083 & $0.96(0.87-1.05)$ & - \\
\hline E2 (pg/mL) & $77.00(50.00-95.00)$ & $73.00(57.00-105.00)$ & 0.553 & $1.00(0.99-1.01)$ & - \\
\hline HOMA-IR & $2.35(1.50-3.20)$ & $1.35(1.08-2.37)$ & 0.01 & $2.25(1.10-4.57)$ & $2.70(1.21-6.01)$ \\
\hline Adiponectin $(\mu \mathrm{g} / \mathrm{mL})$ & $64.67(61.08-68.18)$ & $60.52(59.16-62.30)$ & 0.011 & $1.22(1.03-1.44)$ & - \\
\hline TNF- $\alpha$ & $33.02(12.29-86.05)$ & $15.46(13.13-29.08)$ & 0.288 & $1.00(0.99-1.01)$ & - \\
\hline Osteocalcin (ng/mL) & $1.96(1.45-2.36)$ & $1.01(0.79-1.39)$ & $<0.001$ & $15.39(3.25-72.99)$ & $21.61(3.73-125.27)$ \\
\hline
\end{tabular}

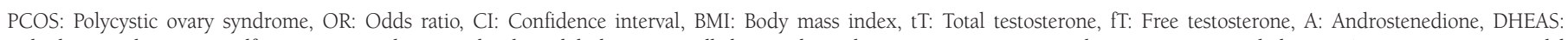

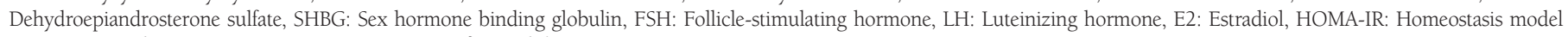
assessment-insulin resistance, TNF- $\alpha$ : Tumor necrosis factor-alpha 
Table 2. Correlation of osteocalcin level with hormonal levels, age, body mass index, homeostasis model assessment-insulin resistance, tumor necrosis factor-alpha, and adiponectin for both groups

\begin{tabular}{lll} 
Variables & $\begin{array}{l}\text { Control group } \\
\text { Osteocalcin } \\
(\mathbf{p})\end{array}$ & $\begin{array}{l}\text { PCOS group } \\
\text { Osteocalcin } \\
(\mathrm{p})\end{array}$ \\
\hline Age & $0.068(0.802)$ & $-0.333(0.027)$ \\
\hline BMI & $0.040(0.882)$ & $0.638(0.027)$ \\
\hline tT & $0.066(0.80)$ & $0.175(0.257)$ \\
\hline fT & $-0.001(0.996)$ & $0.055(0.725)$ \\
\hline A & $0.234(0.383)$ & $-0.139(0.367)$ \\
\hline SHBG & $-0.341(0.196)$ & $-0.041(0.793)$ \\
\hline DHEAS & $0.200(0.458)$ & $0.022(0.889)$ \\
\hline FSH & $-0.086(0.752)$ & $-0.054(0.726)$ \\
\hline LH & $0.021(0.940)$ & $0.154(0.318)$ \\
\hline E2 & $0.337(0.201)$ & $0.054(0.727)$ \\
\hline Adiponectin & $0.671(0.004)$ & $-0.061(0.695)$ \\
\hline TNF- $\alpha$ & $0.344(0.192)$ & $-0.338(0.025)$ \\
\hline HOMA-IR & $0.091(0.736)$ & $-0.155(0.314)$ \\
\hline
\end{tabular}

PCOS: Polycystic ovary syndrome, BMI: Body mass index, tT: Total testosterone, fT: Free testosterone, A: Androstenedione, SHBG: Sex hormone binding globulin, DHEAS: Dehydroepiandrosterone sulfate, FSH: Follicle-stimulating hormone, LH: Luteinizing hormone, E2: Estradiol, TNF- $\alpha$ : Tumor necrosis factor-alpha, HOMA-IR: Homeostasis model assessment-insulin resistance

a state of chronic low grade inflammation. Keeping in mind the anti-inflammatory and anti-DM properties of adiponectin, one could hypothesize that increased adiponectin levels serve to protect patients at high risk of the harmful actions of proinflammatory and DM agents.

Increased levels of TNF- $\alpha$ were detected in PCOS; however, there was no statistical difference between the groups. Although Vural et al. ${ }^{(17)}$ could not illustrate higher TNF- $\alpha$ levels in PCOS, Xiong et al. ${ }^{(18)}$ suggested that patients with PCOS showed significantly higher serum TNF- $\alpha$ levels. The pathogenic impact of TNF- $\alpha$ in IR is underscored by the effect of the functional polymorphisms in the promoter regions of TNF- $\alpha$, with different transcription rates ${ }^{(19)}$, or this situation may be related to the balance of anti-inflammatory and inflammatory agents that are secreted by bone and adipose tissue in PCOS.

More recently, evidence from animal studies suggested that the skeleton may exert an endocrine regulation of glucose metabolism. Lee et al. ${ }^{(20)}$ showed that mice lacking the gene that encodes osteocalcin had an abnormal amount of visceral fat and exhibited glucose intolerance, IR, and impaired insulin secretion compared with wild-type mice. Adami et al. ${ }^{(21)}$ could not illustrate a significant difference between a PCOS group and

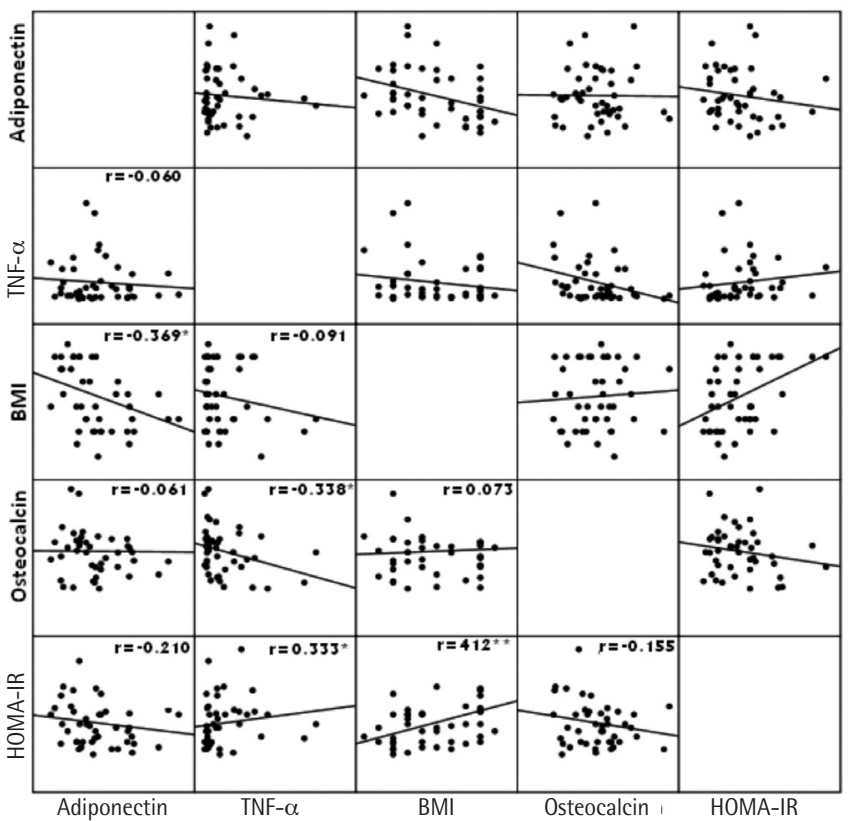

Figure 1. A scatterplot matrix displaying the relationship among body mass index, homeostasis model assessment-insulin resistance, tumor necrosis factor-alpha, adiponectin, and osteocalcin variables

${ }^{*} \mathrm{p}<0.05,{ }^{*} \mathrm{p}<0.01$

HOMA-IR: Homeostasis model assessment-insulin resistance, BMI: Body mass index, TNF- $\alpha$ : Tumor necrosis factor-alpha

control group for osteocalcin, but they found normal androgen levels in their PCOS group; additionally, they did not examine patients for IR. In our study, osteocalcin was significantly increased in PCOS; moreover, there was a negative correlation between osteocalcin and TNF- $\alpha$. Our study is in agreement with Diamanti-Kandarakis et al. ${ }^{(22)}$ who illustrated higher osteocalcin levels in PCOS.

There was no correlation between serum adiponectin and HOMA-IR. There was a moderate negative correlation between osteocalcin and TNF- $\alpha$, in addition to a moderate positive correlation between BMI and HOMA-IR in PCOS. Adiponectin secretion is strongly related with IR rather than obesity, and a previous animal study showed that osteocalcin stimulated the expression of insulin in islets and of adiponectin in adipocytes with increased insulin secretion ${ }^{(23)}$. Perhaps increased osteocalcin levels contribute to high HOMA-IR by increased insulin secretion. Our groups were weight matched and the source of adiponectin was adipose tissue. This situation may explain why we did not detect a correlation between serum adiponectin levels and HOMA-IR.

TNF- $\alpha$ can be released from MNCs and hyperglycemia causes an increase in ROS generation from MNCs. Osteocalcin is defined in the literature with antidiabetic and anti-inflammatory properties, thus a plausible explanation of these events is that increased osteocalcin levels lead to a decrease in TNF- $\alpha$.

\section{Study Limitations}


Due to the relatively small sample size, our results display only weight-matched controls in PCOS. There is a need for further, larger scale studies including interactions between other genetic and environmental factors and the development of PCOS.

\section{Conclusion}

Osteocalcin levels may have impact on adiponectin, TNF- $\alpha$, and IR in PCOS. Therefore, osteocalcin may be responsible for PCOS heterogeneity.

\section{Acknowledgements}

We thank Dr. Faruk Balkaya (English Department of Erciyes University) for his contribution to English terms and language. Erciyes University financially supported this study.

\section{Ethics}

Ethics Committee Approval: The study was approved by the Erciyes University Local Ethics Committee (approval number: 2011-369).

Informed Consent: Consent form was filled out by all participants.

Peer-review: External and internal peer-reviewed.

\section{Authorship Contributions}

Surgical and Medical Practices: G.E., İ.İ.M., Concept: F.B., İ.İ.M., Design: F.B., İ.İ.M., G.A., Data Collection or Processing: G.E., A.T.T., Analysis or Interpretation: G.E., G.B., Literature Search: F.B., İ.I.M., Writing: A.T.T., G.A.

Conflict of Interest: No conflict of interest was declared by the authors.

Financial Disclosure: The authors declared that this study received no financial support.

\section{References}

1. Rotterdam ESHRE/ASRM-Sponsored PCOS Consensus Workshop Group Revised 2003 consensus on diagnostic criteria and longterm health risks related to polycystic ovary syndrome. Fertil Steril 2004:81:19-25.

2. Bayram F, Unluhizarci K, Kelestimur F. Potential utility of insulin sensitizers in the treatment of patients with polycystic ovary syndrome. Treat Endocrinol 2002;1:45-53.

3. Stefan N, Bunt JC, Salbe AD, Funahashi T, Matsuzawa Y, Tataranni PA. Plasma adiponectin concentrations in children: relationships with obesity and insulinemia. J Clin Endocrinol Metab 2002;87:4652-6.

4. Daimon M, Oizumi T, Saitoh T, Kameda W, Hirata A, Yamaguchi $\mathrm{H}$, et al. Decreased serum levels of adiponectin are a risk factor for the progression to type 2 diabetes in the Japanese population: the Funagata study. Diabetes Care 2003;26:2015-20.

5. Snehalatha C, Mukesh B, Simon M, Viswanathan V, Haffner SM, Ramachandran A. Plasma adiponectin is an independent predictor of type 2 diabetes in Asian Indians. Diabetes Care 2003;26:3226-9.

6. Gonzalez F, Rote NS, Minium J, Kirwan JP. Reactive oxygen speciesinduced oxidative stress in the development of insulin resistance and hyperandrogenism in polycystic ovary syndrome. J Clin Endocrinol Metab 2006;91:336-40.

7. Barnes PJ, Karin M. Nuclear factor-B: a pivotal transcription factor in chronic inflammatory diseases. N Eng J Med 1997;336:1066-71.
8. Hotamisligil GS, Murray DL, Choy LN, Spiegelman BM. Tumor necrosis factor inhibits signaling from the insulin receptor. Proc Natl Acad Sci U S A 1994;91:4854-8.

9. de Luis DA, Perez Castirillon JL, Aller R, Izaola O, Bachiller C. Response of osteocalcin and insulin resistance after a hypocaloric diet in obese patients. Eur Rev Med Pharmacol Sci 2015;19:2174-9.

10. Ngarmukos C, Chailurkit LO, Chanprasertyothin S, Hengprasith B, Sritara P, Ongphiphadhanakul B. A reduced serum level of total osteocalcin in men predicts the development of diabetes in a longterm follow-up cohort. Clin Endocrinol 2012;77:42-6.

11. Matthews DR, Hosker JP, Rudenski AS, Naylor BA, Treacher DF, Turner RC. Homeostasis model assessment: insulin resistance and $\beta$-cell function from fasting plasma glucose and insulin concentrations in man. Diabetologia 1985;28:412-9.

12. Chang RJ, Nakamura RM, Judd HL, Kaplan SA. Insulin resistance in nonobese patient with polycystic ovarian disease. J Clin Endocrinol Metab 1983;57:356-9.

13. Dunaif A, Segal KR, Futterweit W, Dobrjansky A. Profound peripheral insulin resistance, independent of obesity in polycystic ovary syndrome. Diabetes 1989;38:1165-74.

14. Vrbikova J, Cibula D, Dvorakova K, Stanicka S, Sindelka G, Hill M, et al. Insulin sensitivity in women with polycystic ovary syndrome. J Clin Endocrinol Metab 2004;89:2942-5.

15. Ducluzeau PH, Cousin P, Malvoisin E, Bornet H, Vidal H, Laville M, Pugeat M. Glucose-to-insulin ratio rather than sex hormone-binding globulin and adiponectin levels is the best predictor of insulin resistance in nonobese women with polycystic ovary syndrome. J Clin Endocrinol Metab 2003;88:3626-31.

16. Frystyk J, Tarnow L, Hansen TK, Parving HH, Flyvbjerg A. Increased serum adiponectin levels in type 1 diabetic patients with microvascular complications. Diabetologia 2005;48:1911-8.

17. Vural P, Degirmencioglu S, Saral NY, Akgul C. Tumor necrosis factor $\alpha$ (-308), interleukin-6 (-174) and interleukin-10 (-1082) gene polymorphisms in polycystic ovary syndrome Eur J Obstet Gynecol Reprod Biol 2010;150:61-5.

18. Xiong YL, Liang XY, Yang X, Li Y, Wei LN. Low-grade chronic inflammation in the peripheral blood and ovaries of women with polycystic ovarian syndrome. Eur J Obstet Gynecol Reprod Biol 2011;159:148-50.

19. Kroeger KM, Carville KS, Abraham LJ. The -308 tumor necrosis factor-a promoter polymorphism effects transcription. Mol Immunol 1997;34:391-9.

20. Lee NK, Sowa H, Hinoi E, Ferron M, Ahn JD, Confavreux C, et al. Endocrine regulation of energy metabolism by the skeleton. Cell 2007;130:456-69.

21. Adami S, Zamberlan N, Castello R, Tosi F, Gatti D. Effect of hyperandrogenism an menstrual cycle abnormalities on bone mass and bone turnover in young women. Clin Endocrinol (Oxf) 1998;48:169-73.

22. Diamanti-Kandarakis E, Livadas S, Katsikis I, Piperi C, Mantziou A, Papavassiliou AG, Panidis D. Serum concentrations of carboxylated osteocalcin are increased and associated with several components of the polycystic ovarian syndrome. J Bone Miner Metab 2011;29:201-6.

23. Wu X, Motoshima H, Mahadev K, Stalker TJ, Scalia R, Goldstein BJ. Involvement of AMP-activated protein kinase in glucose uptake stimulated by the globular domain of adiponectin in primary rat adipocytes. Diabetes 2003;52:1355-63. 